\title{
Brazilian Industrial Defense Base Profile
}

\author{
Perfil da Base Industrial de \\ Defesa do Brasil
}

DOI: $10.21530 /$ ci.v15n3.2020.1054

Ariela Diniz Cordeiro Leske ${ }^{1}$

Thauan Santos ${ }^{2}$

\section{Copyright:}

- This is an open-access article distributed under the terms of a Creative Commons Attribution License, which permits unrestricted use, distribution, and reproduction in any medium, provided that the original author and source are credited.

- Este é um artigo publicado em acesso aberto e distribuído sob os termos da Licença de Atribuição Creative Commons, que permite uso irrestrito, distribuição e reprodução em qualquer meio, desde que o autor e a fonte originais sejam creditados.

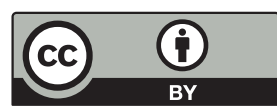

\begin{abstract}
This paper aims to present an overview and analysis of the Brazilian defense industrial base (IDB). Based on the Brazilian Industrial Defense Base Mapping and its eight segments (ABDI-IPEA, 2016), our main contribution is to provide the first national and comparative analysis between these sectors, since there is a lack of knowledge in the literature on the Brazilian defense-related companies scenario. Focusing on the analysis of the international insertion of these companies into the global industry through international trade, we analyze defense-related companies based on (i) personnel and average salaries; (ii) innovative and investment profile; (iii) share of export; (iv) main destination countries; (v) technological intensity of exported products; (vi) main obstacles when looking for external markets; and (vii) main export support instruments. Despite the limitations in terms of data, among the main conclusions stand out that each segment has a specific profile, faces and responds differently to market barriers, and in general its innovative profile is still focused on process, what may limit the competitiveness of companies.
\end{abstract}

Keywords: Brazilian Defense Industry; Industrial Defense Base; Defense Economics; Brazil; Defense.

1 Doutora em Economia da Indústria e da Tecnologia pela Universidade Federal do Rio de Janeiro; Professora Adjunta do Programa de Pós-Graduação em Segurança Internacional e Defesa da Escola Superior de Guerra, Rio de Janeiro, Brasil. (arielaleske@gmail.com). ORCID: https://orcid.org/0000-0002-4995-3940.

2 Doutor em Planejamento Energético pelo Instituto Alberto Luiz Coimbra de Pós-Graduação e Pesquisa de Engenharia. Professor Adjunto do Programa de Pós-Graduação em Estudos Marítimos da Escola de Guerra Naval, Rio de Janeiro, Brasil.

(santos.thauan@gmail.com). ORCID: https://orcid.org/0000-0002-4001-4322.

Artigo submetido em 03/03/2020 e aprovado em 17/06/2020. 


\section{Resumo}

Este artigo tem como objetivo apresentar uma visão geral e uma análise da base industrial de defesa (BID) brasileira. Com base no Mapeamento da Base de Defesa Industrial Brasileira e em seus oito segmentos (ABDI-IPEA, 2016), nossa principal contribuição é fornecer a primeira análise nacional e comparativa entre esses setores, uma vez que há um desconhecimento na literatura sobre o cenário das empresas brasileiras relacionadas à defesa. Com foco na análise da inserção internacional dessas empresas na indústria global por meio do comércio internacional, analisamos empresas relacionadas à defesa com base em (i) pessoal e salários médios; (ii) perfil inovador e de investimento; (iii) participação na exportação; (iv) principais países de destino; (v) intensidade tecnológica dos produtos exportados; (vi) principais obstáculos ao buscar mercados externos; e (vii) principais instrumentos de apoio à exportação. Apesar das limitações em termos de dados, dentre as principais conclusões destacam-se que cada segmento tem um perfil específico, enfrenta e responde diferentemente às barreiras de mercado e, em geral, seu perfil inovador ainda está focado em processos, o que pode limitar a competitividade das empresas.

Palavras-chave: Indústria de Defesa Brasileira; Base Industrial de Defesa; Economia de Defesa; Brasil; Defesa.

\section{Introduction}

In order to expand the consumer market, defense companies seek to export their products in addition to acting in the commercial market; in some cases, export is actually a necessary condition for their survival. Therefore, this paper aims to describe the profile of exports of companies related to national defense, identify the relevant factors of exports in this area and what are their main weaknesses in the Brazilian defense-related companies.

We use data published by the Brazilian Industrial Defense Base Mapping (ABDI-IPEA 2016). Eight segments are considered, namely: light and heavy weapons and ammo and explosives (A); electronic systems and command and control systems (B); military naval platform (C); nuclear propulsion (D); military ground platform (E); military aircraft platform (F); defense-oriented space systems (G); and equipment for individual use $(\mathrm{H})$. These segments will be analyzed jointly in terms of the following factors related to exports: (i) personnel and average salaries; (ii) innovative and investment profile; (iii) share of export; (iv) main destination countries; (v) technological intensity of exported products; (vi) main obstacles when looking for external markets; and (vii) main export support instruments. 
The paper will be structured as follows: first, and after this brief introduction, there will be a section that presents the empirical review on international trade in the defense sector, with a particular focus on exports. Then, there will be a brief description of the Brazilian defense industry, based on the Brazilian Industrial Defense Base Mapping. Next, we present the data on the Brazilian Industrial Defense Base (IDB)'s international insertion. Finally, we show some conclusions and reflections on the nature, profile and challenges faced by the Brazilian defense industries.

\section{International trade and some aspects of defense area}

When it comes to international trade, it is often interesting to analyze the issue from a regional perspective. Within the scope of regional South American initiatives, the Union of South American Nations (UNASUR) stands out, especially for giving much relevance to the area of defense due to the South American Defense Council (CDS). We particularly emphasize the importance of UNASUR in relation to increased (regional) demand, the stimulus to Brazilian exports of certain companies operating in the defense sector, and the internationalization of some of these companies.

Although its creation has contributed to the complexification and overlap of South American security and defense structures (Villa e Bragatti 2015), the CDS advanced significantly in the field of confidence and cooperation measures in defense industries and technologies in the region (Souza 2016; Pagliari 2015), contributing to the deepening of the regional integration process (Martinez e Lyra 2018). Since its creation in 2008, seeking to overcome the mistrust existing in the region and to incorporate the defense sector as an harmonic pillar to facilitate the process of regional integration (Arredondo 2017), the CDS constitutes itself as an instance of consultation, cooperation and defense coordination (AbdulHak 2013).

Its decisions were taken in consensus and respect for the diversity, desires, values and traditions of each member state; they were only declaratory, without a legally binding nature (Santos 2018a), therefore, it was not an operational alliance along the lines of the North Atlantic Treaty Organization (NATO). As its main objectives, the CDS proposes: (i) to consolidate South America as a zone of peace, the basis for democratic stability and the integral development of its 
peoples, as a contribution to world peace; (ii) to build a South American defense identity, which takes into account sub-regional and national characteristics, and which contributes to strengthening the unity of Latin America and the Caribbean (LAC); and (iii) to generate consensus to strengthen regional defense cooperation (Aranguiz 2013).

One of the central points of the CDS is the possibility of resumption of the defense industry, considering the complementarity of the production chain and the scale amplitude. Thus, in seeking to rearticulate a Defense Industrial Base (IDB) with a South American foundation, the CDS presents the possibility of working on the construction of a South American defense industry, with a broad market driven by state orders and with the participation of companies in their countries (Padula 2015).

However, given the recent breakdown of UNASUR and CDS after 2018 (Fuccille 2018; Santos, Rodrigues e Leite 2019), as well as the relevance of Brazil with regard to the defense budget, expenditure and investments in South America (Rezende 2016), the focus of this paper will be only on the case of the Brazilian defense industrial base. Therefore, in this section, the intention is to narrow and tie the relationship between international trade, exports, innovation and internationalization of companies, and then to specifically analyze the Brazilian IDB case.

According to the classic theories of international trade, trade between countries should focus on their comparative advantages - whether absolute or relative. In the early decades of the twentieth century, the Heckscher (1991) and Ohlin (1991) models indicated that the factor endowment of each economy would determine its exports and imports. However, in the 1970s Chamberlian hypotheses of product differentiation, economies of scale, and monopolistic competition emerged, overcoming the simplified models that assumed pure and perfect competition and often ignored market failures. In the "new" trade theory (Helpman 1981; Krugman 1981), North-South trade was associated with traditional comparative advantages determined by the intensity of factors of production and with inter-industry trade, whereas North-North trade would be based on economies of scale and product differentiation, being associated with intra-industry trade.

In general, exports are considered as a factor that can contribute to economic growth, either through the direct effect on the GDP, or through an increase in the scale of production and productivity (Balassa 1978; Balassa 1985; Delgado, 
Fariñas e Ruano 2002; Cuaresma e Wörz 2005). This increase can derive from learning through interaction with producers and consumers, resulting in the use of new technologies and greater productivity, in a process called learning-byexporting (Salomon e Shaver 2005). The learning-by-exporting process also seems to be influenced by the technological intensity of the companies. The greater the technological intensity, the greater the learning-by-exporting (Fernandes e Isgut 2005). Besides, countries with more experience produce and export goods with high technological content (Catella e Gonçalves 2011).

On the one hand, companies can start the export process based on successful innovations in the domestic market. Internal success can stimulate the company to enter the international market (Vernon 1966). On the other hand, there is the possibility of companies that export have also a greater tendency to innovate, since exporting leads to process innovations, increasing productivity (Álvarez e García 2008; Damijan, Kostevc e Polanec 2010). Also, the improvement of the size of markets and the induces of the knowledge spillovers are effects that can be appropriated by successful innovators (Vernon 1966; Aghion e Howit 2009; Aghionet al. 2018; Grossman e Helpman 1989). Consequently, the larger and more productive companies would be even more likely to innovate and, consequently, to export (Melitz 2003; Caldera 2010; Raiher, Carmo e Stege, 2017; Lo Turco e Maggioni 2014; Suárez-Porto e Guisado-González 2014).

In this sense, firm-technological resources can be an important factor for international competitiveness (Rodríguez e Rodróguez 2005). Technological advances and delays can be considered critical for international competitiveness in medium and high technology goods (Dosi, Lechevalier e Secchi 2010; Dosi, Pavitt e Soete 2009), with differences in products and production processes being central to the competitive process, thus increasing the likelihood of insertion into international markets (Dosi, Grazzi e Moschella 2015). Atkeson and Burstein (2010) suggest that the product innovation can offset a change in trade costs, having a substantial impact on heterogeneous firms exit, export, and process innovation decisions. That product innovation has an important moderating effect on the positive association between exports and productivity (Cassiman e Golovko 2011). For Becker and Egger (2013), there is significant bias of the impact of product and process innovations on exports. The result was particularly large for firms with only product or process innovations as compared to firms that did not innovate. 
The exchange rate depreciation can be also an important part of growth accelerations and may improve welfare if there is a market failure that affects the tradables sector more than the nontradable sector (Hausmann, Hwang e Rodrik 2005; Rodrik 2007). In some cases, it has been observed that export growth can be preceded by significant exchange rate depreciation because it tends to facilitate the commercialization of new products and entry into new markets (Freund e Pierola 2012).

When it comes particularly to defense sector, there are some peculiarities, especially after the Cold War, when the international arms market experienced a dramatic structural change (Anderton 1995). Until the end of the Cold War, the state's political regime - whether it was democratic or not - was a common concern. It is suggested that post-cold war policies have not mattered (Perkins e Neymayer 2002), since "democracies have not been as altruistic or ethical as they have claimed in recent years” (Akerman e Seim 2014, 23). Still after the Cold War, the conflicts have presented smaller proportions, and for that reason it is possible to observe greater relevance in the trade of small arms (Kinsella 2011).

The defense international trade is even surrounded by a dichotomy in terms of political decision: importing or producing domestically (Levine et al. 1997). Regardless the choices, it is indeed necessary to allocate a significant amount of resources. The imports do not require long-term commitment, nor do they contribute economically (job creation and industrial training) or reduce subordination in the global arms transfer and production system (Krause 1995). The national production requires constant investment in $R \& D$ and productive incentives, in addition to purchases that must be made by the State, at least initially (Santos 2018b; Leske 2015, 2018). The second case offers some positive externalities such as encouraging industrial production in higher value-added sectors and skilled labor. The model tested by Levine et al. (1997) show some variety of arms control policies that can increase welfare, including coordination, price transparency and common arms export policy.

It is worth noting that the international arms transfer system has changed in many levels after the end of the Cold War, with its overall volume reduced mainly because of the strong decline in exports of the Soviet Union (USSR) and its successor states (Brzoska 2004; Garcia-Alonso e Levine 2007). The arms market has become more diverse, both in terms of supplier-recipient relationships and of the types of weapons used. Buyers with financial resources bought expensive weapons, predominantly from the United States (US) and Western Europe, while 
the others bought old weapons and small arms. Even the donations, which were very common during the Cold War, were reduced (Brzoska 2004). However, more recently, Villa and Weiffen (2014) highlight that the increase in arms spending cannot be understood if one does not consider the coexistence of a stable power balance in a regional security governance, as well as the desire of emerging states to increase their regional or global roles.

Among the consequences, the reduction in this market is the reorganization of productive structures. Many international companies closed, merged or were incorporated, consolidating the industry and consequently concentrating production on few companies and further narrowing the economically viable segments (Dunne 1995). Exports in the United Kingdom (UK) for instance decreased by $50 \%$ in the late 1990s, resulting in significant losses for gross domestic product (GDP) and reallocation of resources in alternative occupations (Sharp 2005). A recent study indicates that exporting countries tend to reduce their military budgets (Pamp e Thurner 2017). Other benefits can come from a greater insertion in the international market, such as: firms will progressively become more efficient, less dependent on public procurement and innovation policy support, as well as more prone to knowledge sharing and inter-firm collaboration (Blom, Castellacci e Fevolden 2014).

With this consolidation, developing arms-producing countries remain dependent on imports of sophisticated critical subsystems, and little transfer of the knowledge necessary to go beyond simple reproduction or copying of weapons took place (Krause 1992). More developed countries have then increased their military technological advantages compared to developing countries (Brzoska 2004), reinforcing a market structure in which the roles of technology and knowledge producers and importers are clearly defined and relatively static. Consequently, this scenario implies in companies whose innovative processes are characterized by imitation and incremental innovations (Freeman e Soete 2008), contributing only marginally to the reintegration of these countries in this international trade. As a result, commercialization and differentiation in the international arms market imply that economic and military power are becoming closer, reinforcing the status of inequality between developed and developing countries in international trade in defense.

Fonfría and Duch-Brown (2014) stress the role of technological issues when analyzing the performance of exports of the Spanish defense industry between 2003 and 2008. The authors argued that more intense exporters of defense 
material are more productive and, consequently, more involved in export and technological activities. However, the intense regulation and political intervention in the trade related to defense products tends to generate additional costs and coexist with a parallel trade of military products. This latter factor may cause trade-related studies in this area to be underestimated.

Finally, it is important to highlight the difficulty of adequately analyzing indicators on production and trade. In terms of secondary data, the Stockholm International Peace Research Institute (SIPRI) and the Military Balance (IISS) are usually the most viable. Only the former is freely accessible, but its data are aggregated by country, except for the information available on the top 100 companies in the area. In this sense, the next section wishes to contribute providing a more detailed information regarding the production and foreign trade of Brazilian companies that supply defense products.

\section{The Brazilian IDB: What does the Mapping show?}

\section{Mapping features}

The Brazilian Industrial Defense Base Mapping is the first effort undertaken in Brazil with the objective to size and know the micro-data related companies that provide defense products. The mapping was elaborated between 2014-2015 by the National Agency for Industrial Development (ABDI) and the Institute of Applied Economic Research (IPEA), in addition to eight Brazilian specialists contracted for this research, and the results were published in 2016. This was carried out to better understand companies related to national defense.

The purpose of the research was to identify companies that supply defense products and their main characteristics, such as their size, employees' profile and the share that defense plays in these companies. As each segment was analyzed individually — and with some autonomy and particularity — , here we intend to carry out a joint and common analysis, allowing an overview of the Brazilian IDB - constituting the main contribution of this paper to the specialized literature.

The number of companies analyzed is based on data from the Annual Social Information Report (RAIS) (2003-2011) and differs from the number of companies that gave rise to data on international insertion (2003-2013), as well as from those that constitute the sample of innovation data (2000-2011). This mismatch between 
the periods analyzed is due to the lack of existing data. Data provided by RAIS and Research of Technological Innovation (PINTEC) have different collection periods, since RAIS is an annual research and PINTEC is carried out every 3 years. Despite the discrepancy between the collection periods, these are the only data available to companies in the selected area. In relation to the primary data, there is also a reduction in the sample due to the number of companies that have responded to the questionnaires carried out by the specialists.

\section{A synthesis of the Brazilian IDB}

Table 1 shows the number of companies selected to compose the sample by segments. The segments with the largest sample are (F) aircraft (34.3\%) and (C) naval (33.6\%), followed by (B) electronic systems (12.3\%) and (G) space systems $(9.8 \%)$, respectively. The segment with the lowest number of companies is (A) weapons, ammo and explosives (2.2\%). $86 \%$ of the selected companies were picked up by RAIS and, over the period, the number of captured companies increased by an average of $27 \%$ between 2003 and 2011, while the total number of employed personnel increased by an average of $79 \%$ over the same period.

Table 1. Number of defense-related companies, employed personnel and average salary (2003-2011)

\begin{tabular}{|c|c|c|c|c|c|c|c|c|c|}
\hline \multirow[t]{2}{*}{ Segments $^{3}$} & \multirow[t]{2}{*}{$\begin{array}{l}\text { Number of } \\
\text { companies }\end{array}$} & \multicolumn{2}{|c|}{$\begin{array}{c}\text { Number of } \\
\text { Companies at } \\
\text { RAIS }\end{array}$} & \multicolumn{2}{|c|}{$\begin{array}{l}\text { Employed } \\
\text { personnel }\end{array}$} & \multicolumn{2}{|c|}{$\begin{array}{l}\text { Higher-level } \\
\text { personnel* }\end{array}$} & \multicolumn{2}{|c|}{$\begin{array}{c}\text { Average salary } \\
(\mathbf{R} \$)^{* *}\end{array}$} \\
\hline & & 2003 & 2011 & 2003 & 2011 & 2003 & 2011 & 2003 & 2011 \\
\hline A & 23 & 15 & 16 & 4,888 & 6,561 & $17 \%$ & $22 \%$ & $2,744.00$ & $4,101.00$ \\
\hline B & 130 & 73 & 100 & 7,778 & 16,229 & $38 \%$ & $48 \%$ & $4,204.00$ & $4,576.00$ \\
\hline $\mathrm{C}$ & 355 & 259 & 324 & 46,170 & 92,214 & $3 \%$ & $5 \%$ & $2,926.00$ & $3,388.00$ \\
\hline $\mathrm{D}$ & 34 & 23 & 28 & 2,443 & 3,987 & $22 \%$ & $21 \%$ & $3,047.00$ & $4,031.00$ \\
\hline $\mathrm{E}$ & 48 & 27 & 40 & 12,479 & 23,896 & $17 \%$ & $28 \%$ & $4,105.00$ & 4.379 .00 \\
\hline $\mathrm{F}$ & 362 & 241 & 312 & 16,013 & 26,946 & $18 \%$ & $25 \%$ & $2,851.00$ & 3.186 .00 \\
\hline G & 104 & 71 & 84 & 3,632 & 6,852 & $30 \%$ & $42 \%$ & $3,113.00$ & 3.690 .00 \\
\hline Total & 1056 & 709 & 904 & 93,405 & 176,685 & - & - & $22,990.00$ & $27,351.00$ \\
\hline Mean & 150.86 & 101.29 & 129.14 & 13,344 & 25,241 & $20.7 \%$ & $27.3 \%$ & $3,284.29$ & $3,907.29$ \\
\hline
\end{tabular}

Source: Own elaboration based on ABDI-IPEA (2016); * share of total; ** in order to convert reais (R\$) to US dollars (US\$), use the exchange rate values in Appendix 1.3

3 Light and heavy weapons and ammo and explosives (A); electronic systems and command and control systems (B); military naval platform (C); nuclear propulsion (D); military ground platform (E); military aircraft platform (F); defense-oriented space systems (G); and equipment for individual use $(\mathrm{H})$. 
Regarding the profile of employed personnel, there is a significant concentration in the naval segment (C), which represents $52.2 \%$ of the total in 2011. As a result, this segment has the lowest percentage of workers with a higher level $(5.0 \%)$ and the second lowest average salary ( $\mathrm{R} \$ 3,388.00)$.

Then, it is possible to conclude that the percentage of employed personnel in different segments of the Brazilian IDB with a higher level is well above the national average. While some segments reach 48\% (B) and, on average, higher level personnel represent $27.3 \%$, the national average according to the IBGE (2013) is only $15 \%$ of the total employed personnel. Between 2003 and 2011, there was an increase of $35 \%$, on average, in the share of personnel with higher education, but the average salary increased only $20 \%$. Despite a relatively small growth rate, the average salary at the Brazilian IDB is still higher than the national average which, according to IBGE (2014), was only R\$1,943.00 in 2012.

In order to investigate the relationship between the companies and the national defense, questionnaires were sent to the companies that made up the sample of the mapping4. Only the electronic systems and command and control systems (B) and nuclear propulsion (C) segments have defense as their main market, since the other segments carry out most of their sales in the commercial market (ABDI-IPEA, 2016). This is one of the main findings of this paper, since Brazil has different policies and fiscal instruments directed to "defense companies" that in fact are actually supplying more commercial market rather than defense market itself.

The innovative profile of the companies that compose the sample can be observed from the data of the Research of Technological Innovation (PINTEC) and are presented in Table 2. PINTEC seeks to capture some indicators on innovation in the country and provides a series of data on the innovative process of national companies, through a cross-section following the conceptual aspects proposed in the Oslo manual (IBGE, 2011) ${ }^{5}$. Due to financial costs associated with the analysis of all national companies, the survey was carried out by sampling.

4 The maximum percentage of responses was observed in the arms and ammo segment (A), where $30 \%$ of the companies previously selected responded to the questionnaire. In the ground platform segment (E), only $10 \%$ of companies responded. Overall, only $17 \%$ of companies answered the questionnaire on average.

5 Regardless of the progress made in PINTEC's methodology, it still relies on traditional indicators, leaving aside some qualitative and often specific indicators to sectors and companies, making them the target of criticism about their real ability to capture important systemic aspects. 
Table 2. Defense-related companies that innovated and their investment in innovation (PINTEC, 2000-2011)

\begin{tabular}{c|r|r|r|r|r|r|r|r}
\hline \multirow{2}{*}{ Segments } & \multicolumn{2}{|c|}{$\begin{array}{c}\text { Companies at } \\
\text { PINTEC }\end{array}$} & \multicolumn{2}{c|}{$\begin{array}{c}\text { Innovative } \\
\text { Companies }\end{array}$} & \multicolumn{2}{c|}{$\begin{array}{r}\text { Investment in innovation } \\
\text { (R\$) }\end{array}$} & \multicolumn{2}{c}{ Investment rate } \\
\cline { 2 - 9 } & $\mathbf{2 0 0 0}$ & $\mathbf{2 0 1 1}$ & $\mathbf{2 0 0 0}$ & $\mathbf{2 0 1 1}$ & \multicolumn{1}{|c|}{$\mathbf{2 0 0 0}$} & $\mathbf{2 0 1 1}$ & $\mathbf{2 0 0 0}$ & $\mathbf{2 0 1 1}$ \\
\hline A & 9 & 8 & 8 & 5 & $20,232.00$ & $59,024.00$ & $5.0 \%$ & $3.9 \%$ \\
B & 17 & 30 & 13 & 24 & $209,142.00$ & $274,157.00$ & $4.4 \%$ & $0.5 \%$ \\
C & 75 & 142 & 46 & 71 & $245,413.00$ & $628,340.00$ & $3.8 \%$ & $1.8 \%$ \\
D & 9 & 10 & 5 & 6 & $51,116.00$ & $35,483.00$ & $6.2 \%$ & $2.2 \%$ \\
E & 7 & 17 & 6 & 13 & $56,132.00$ & $2,746,458.00$ & $3.1 \%$ & $3.3 \%$ \\
F & 42 & 81 & 31 & 39 & $445,398.00$ & $1,434,383.00$ & $7.3 \%$ & $9.3 \%$ \\
G & 8 & 22 & 6 & 15 & $9,854.00$ & $167,166.00$ & $11.3 \%$ & $6.6 \%$ \\
\hline TOTAL & $\mathbf{1 5 9}$ & $\mathbf{2 8 8}$ & $\mathbf{1 0 9}$ & $\mathbf{1 7 3}$ & $\mathbf{1 , 0 3 7 , 2 8 7}$ & $\mathbf{5 , 3 4 5 , 0 1 1 . 0 0}$ & - & - \\
Mean & $\mathbf{2 7}$ & $\mathbf{4 8}$ & $\mathbf{1 6 , 4}$ & $\mathbf{2 4 , 7}$ & $\mathbf{1 4 8 , 1 8 3 . 9 0}$ & $\mathbf{7 6 3 , 5 7 3 . 0 0}$ & $\mathbf{5 . 9 \%}$ & $\mathbf{3 . 9} \%$ \\
Median & $\mathbf{1 3}$ & $\mathbf{2 4}$ & $\mathbf{8}$ & $\mathbf{1 5}$ & $\mathbf{5 6 , 1 3 2 . 0 0}$ & $\mathbf{2 7 4 , 1 5 7 . 0 0}$ & $\mathbf{5 . 0} \%$ & $\mathbf{3 . 3} \%$ \\
\hline
\end{tabular}

Source: Own elaboration based on ABDI-IPEA (2016).

The investment rate in innovation, which represents how much companies invest in innovation in terms of its sales revenue, was on average $5.9 \%$ in 2000 , but decreased to $3.9 \%$ in 2011. There was a significant drop in the (D) nuclear propulsion segments (-4 pp), (B) electronic systems (-3.9 pp) and (C) naval platform ( $-2 \mathrm{pp})$. If we consider only domestic research and development (R\&D) investment, its average as a function of company revenues was $1.9 \%$, while the national average as a whole was $0.84 \%$ (IBGE 2011). Therefore, despite its reduction in the proportion invested, the group of companies related to the Brazilian IDB still presents a more innovative profile than the national industry average - which is in line with the higher level of employed personnel and then its average salary in the Brazilian IDB.

Among the mapping companies, on average only $19 \%$ were analyzed by PINTEC. The segment with the largest participation in PINTEC was the naval platform (C), in which, from an initial list of 355 companies, only 142 were part of PINTEC in 2011. The space segment $(G)$ was the smaller segment, with only $21 \%$ in the same period. Between 2000 and 2011, the number of companies analyzed by PINTEC increased $85 \%$ (among those making up the sample). Due to such increase, it is hard to identify if the increase in the number of companies that innovated was due to the amount of companies itself or if companies that already have been part of the research started to innovate. 
The innovative profile is also captured by PINTEC (see Table 3). For sample data, product innovation was implemented by about $10 \%$ more companies than those implementing process innovations over the period. Between 2000 and 2011, there was a reduction in the number of companies in the weapons (A) and ground platform (E) segments that introduced product innovations. The fact that the naval segment $(\mathrm{C})$ has a larger sample within PINTEC ends up reflecting the number of companies that introduced innovations in general.

Table 3. Innovative profile of defense-related companies (PINTEC, 2000-2011)

\begin{tabular}{c|c|c|c|c|c|c|c|c|c}
\hline \multirow{2}{*}{ Segment } & Year & Total & $\begin{array}{c}\text { New } \\
\text { to the } \\
\text { company }\end{array}$ & $\begin{array}{c}\text { New to } \\
\text { the } \\
\text { national } \\
\text { market }\end{array}$ & Total & $\begin{array}{c}\text { New } \\
\text { to the } \\
\text { company }\end{array}$ & $\begin{array}{c}\text { New to } \\
\text { the } \\
\text { national } \\
\text { market }\end{array}$ & $\begin{array}{c}\text { Product } \\
\text { and } \\
\text { process }\end{array}$ & TOTAL \\
\hline \multirow{2}{*}{ A } & 2000 & 10 & 4 & 6 & 9 & 4 & 5 & 7 & 26 \\
& 2011 & 5 & 2 & 3 & 5 & 4 & 1 & 3 & 13 \\
\hline \multirow{2}{*}{ B } & 2000 & 17 & 8 & 9 & 11 & 5 & 6 & 8 & 36 \\
& 2011 & 28 & 11 & 17 & 20 & 12 & 8 & 20 & 68 \\
\hline \multirow{2}{*}{ C } & 2000 & 51 & 25 & 26 & 46 & 30 & 16 & 27 & 124 \\
& 2011 & 72 & 36 & 36 & 72 & 53 & 19 & 49 & 193 \\
\hline \multirow{2}{*}{ E } & 2000 & 7 & 4 & 3 & 7 & 2 & 5 & 4 & 18 \\
& 2011 & 8 & 3 & 5 & 7 & 5 & 2 & 6 & 21 \\
\hline \multirow{2}{*}{ F } & 2000 & 26 & 13 & 13 & 8 & 5 & 3 & 6 & 40 \\
& 2011 & 14 & 5 & 9 & 15 & 10 & 5 & 13 & 42 \\
\hline \multirow{2}{*}{ G } & 2000 & 26 & 13 & 13 & 25 & 13 & 12 & 15 & 66 \\
& 2000 & 31 & 12 & 19 & 38 & 26 & 12 & 25 & 94 \\
\hline
\end{tabular}

Source: Own elaboration based on ABDI-IPEA (2016).

Since it influences exports, product innovation has been shown to be relatively more important than process innovation (Dosi, Grazzi e Moschella 2015). In this sense, defense-related companies are acting jointly towards a better international insertion, although still relatively low if we consider the selected sample. Despite the fact that most of the segments of this sample operate in the commercial market, according to the companies' perception, the spin-off $(27 \%)$ has been slightly higher than spin-in (22\%). On average, $27 \%$ of respondents argued to have developed technologies for military purposes and then used in the commercial market (IPEA-ABDI, 2016). 
In this context, in a summarized and partly conclusive way, the mapping data indicates that the Brazilian IDB operates in a dual perspective (Dagnino 2008). Despite the fact that they operate mostly in the commercial market, defense-related companies are able to meet the specific demands of the defense sector. This is fundamental in a country like Brazil, where the demand for military products is low and unstable. This characteristic of demand is a result of the country's not involving in wars in its recent history and the large concentration of the Ministry of Defense (MD) budget in personnel expenditures (Matos, Fingolo e Schneider 2017). Another consequence of the low demand of the national armed forces is the importance that the exports assumed: besides expanding the commercial consumer market, they can also help maintain a minimum production capacity for defense. Therefore, the next section will present different data on the export of defense-related companies in Brazil.

\section{The International Insertion of the Brazilian IDB}

\section{Defense-related companies exports profile}

Between 2003 and 2010, the number of companies that exported grew slightly. In the segments of arms (A) and nuclear propulsion (D), more than half of the companies exported. Notwithstanding, in others such as electronics (B) and space (G) the percentage was below $30 \%$. Therefore, Table 4 shows that international insertion of these firms is still limited, since the number of companies that export is on average as high as $40 \%$.

Table 4. Share of export by defense-related companies (2003-2010)

\begin{tabular}{c|c|c|c|c|c|c|c|c}
\hline Year & $\mathbf{2 0 0 3}$ & $\mathbf{2 0 0 4}$ & $\mathbf{2 0 0 5}$ & $\mathbf{2 0 0 6}$ & $\mathbf{2 0 0 7}$ & $\mathbf{2 0 0 8}$ & $\mathbf{2 0 0 9}$ & $\mathbf{2 0 1 0}$ \\
\hline A & $59 \%$ & $59 \%$ & $53 \%$ & $59 \%$ & $59 \%$ & $71 \%$ & $65 \%$ & $65 \%$ \\
B & $18 \%$ & $22 \%$ & $18 \%$ & $23 \%$ & $22 \%$ & $21 \%$ & $24 \%$ & $26 \%$ \\
C & $28 \%$ & $26 \%$ & $27 \%$ & $32 \%$ & $30 \%$ & $34 \%$ & $38 \%$ & $37 \%$ \\
D & $38 \%$ & $35 \%$ & $38 \%$ & $32 \%$ & $47 \%$ & $35 \%$ & $41 \%$ & $53 \%$ \\
E & $31 \%$ & $33 \%$ & $35 \%$ & $42 \%$ & $33 \%$ & $40 \%$ & $44 \%$ & $42 \%$ \\
F & $19 \%$ & $20 \%$ & $20 \%$ & $27 \%$ & $27 \%$ & $25 \%$ & $29 \%$ & $29 \%$ \\
G & $14 \%$ & $18 \%$ & $16 \%$ & $19 \%$ & $17 \%$ & $18 \%$ & $20 \%$ & $24 \%$ \\
\hline
\end{tabular}

Source: Own elaboration based on ABDI-IPEA (2016). 
Table 5 shows the top 10 destination countries of defense-related companies' export between 2008 and 2013. It can be seen that the top 10 accounted for $66.5 \%$ of the destination of exports (2008) and reached $84.7 \%$ (2013), indicating a greater dependence on these markets and a reduction in the diversification of the main partners. In 2013, the main destinations were the U.S. (38.3\%), Argentina (18.0\%) and Venezuela (6.1\%), totaling US\$ 4,645.4 billion. Among the other countries with significant share of exports in 2013, stand out the U.K. (1.9\%), Italy (1.8\%), Azerbaijan (1.7\%) and Colombia (1.6\%).

Table 5. Top 10 destination of defense-related companies' export (2008-2013)

\begin{tabular}{l|c|c|c|c|c|c}
\hline \multicolumn{1}{c|}{ Countries } & $\mathbf{2 0 0 8}$ & $\mathbf{2 0 0 9}$ & $\mathbf{2 0 1 0}$ & $\mathbf{2 0 1 1}$ & $\mathbf{2 0 1 2}$ & $\mathbf{2 0 1 3}$ \\
\hline U.S. & $38.6 \%$ & $31.1 \%$ & $19.9 \%$ & $21.4 \%$ & $23.9 \%$ & $38.3 \%$ \\
Argentina & $15.8 \%$ & $14.7 \%$ & $28.7 \%$ & $30.5 \%$ & $18.0 \%$ & $18.0 \%$ \\
Venezuela & $0.8 \%$ & $1.5 \%$ & $2.2 \%$ & $1.3 \%$ & $2.7 \%$ & $6.1 \%$ \\
Ireland & - & - & - & - & $2.2 \%$ & $5.1 \%$ \\
China & $2.7 \%$ & $6.3 \%$ & $6.2 \%$ & $9.2 \%$ & $13.3 \%$ & $5.0 \%$ \\
Chile & $3.1 \%$ & $1.7 \%$ & $3.4 \%$ & $4.1 \%$ & $4.9 \%$ & $3.5 \%$ \\
Kenya & - & - & - & - & $2.7 \%$ & $2.3 \%$ \\
Brussels & $1.7 \%$ & $0.0 \%$ & $0.0 \%$ & $0.0 \%$ & $0.3 \%$ & $2.3 \%$ \\
Mexico & $2.1 \%$ & $1.3 \%$ & $1.5 \%$ & $4.1 \%$ & $4.8 \%$ & $2.2 \%$ \\
South Africa & $1.8 \%$ & $2.1 \%$ & $2.1 \%$ & $1.9 \%$ & $1.6 \%$ & $1.9 \%$ \\
Others & $33.5 \%$ & $41.2 \%$ & $36.0 \%$ & $27.2 \%$ & $25.6 \%$ & $15.3 \%$ \\
\hline Total (millions) & $7,899.60$ & $5,539.40$ & $6,013.10$ & $6,841.90$ & $7,338.70$ & $7,444.10$ \\
Mean (millions) & 246.9 & 184.6 & 214.8 & 213.8 & 222.4 & 240.1 \\
Median (millions) & 120.3 & 77.4 & 96.0 & 76.3 & 50.2 & 91.8 \\
\hline
\end{tabular}

Source: Own elaboration based on ABDI-IPEA (2016).

These top 10 countries comes from different natures: (i) regional integration and strategic environment; (ii) international cooperation - south-south cooperation (SSC); and (iii) historical trade relationships. In the first case, Latin American countries in general stand out, such as Argentina, Venezuela, Chile and Mexico; in the second case, it arises from particularly international cooperation arrangements such as BRICS (China and South Africa); finally, the third case is due to Brazil's historical trade tradition with top five partners, such as the U.S. and the EU. In the first two cases, it may be associated with the narrowing or the search for closer approximation with countries of the Global South through Brazilian foreign policy (BFP) in the period in question. 
With regard to its foreign policy agenda, Brazil has also avoided hard power strategies, for example by renouncing nuclear weapons while joining the Nuclear Non-Proliferation Treaty (NPT) (Carranza 2017). This nature of Brazilian foreign policy differs from the case of arms production in Asia, which "is heavily influenced by concepts of techno-nationalism, which views autarky (self-sufficiency in armaments) as serving not only national defense needs, but also as maximizing national political, strategic, and economic autonomy" (Bitzinger 2015, 453).

In terms of quality, data are more encouraging. Data on the technological intensity of exported products shows that these tend to be higher value-added products. The Organization for Economic Cooperation and Development (OECD) classifies the industrial sectors based on the level of technological intensity in the 34 countries that make up its base (OECD 2015). Through the "technological intensity” indicator, industrial sectors are classified into four levels: high, medium-high, medium-low and low (Hatzinchronoglou 1997; OECD 2011). Table 6 shows how it applies to defense-related companies.

Table 6. Value exported from defense-related companies based on technological intensity of exported products, in millions of dollars (2008-2013)

\begin{tabular}{c|c|c|c|c|c|c|c}
\hline \multirow{2}{*}{ Segment } & Year & $\begin{array}{c}\text { Total } \\
\text { exported } \\
\text { value }\end{array}$ & $\begin{array}{c}\text { High } \\
\text { intensity }\end{array}$ & $\begin{array}{c}\text { Medium- } \\
\text { high } \\
\text { intensity }\end{array}$ & $\begin{array}{c}\text { Medium- } \\
\text { low } \\
\text { intensity }\end{array}$ & $\begin{array}{c}\text { Low } \\
\text { intensity }\end{array}$ & $\begin{array}{c}\text { Non- } \\
\text { industrial }\end{array}$ \\
\hline \multirow{2}{*}{ A } & 2008 & 284.0 & 5.0 & 278.8 & 0.0 & 0.1 & 0.0 \\
\hline B & 2013 & 425.1 & 1.0 & 422.7 & 0.7 & 0.5 & 0.2 \\
\hline C & 2008 & 29.9 & 19.5 & 9.9 & 0.3 & 0.2 & 0.0 \\
\hline D & 2013 & 58.0 & 31.6 & 25.6 & 0.5 & 0.3 & 0.0 \\
\hline E & 2013 & $1,582.4$ & 50.2 & $1,398.3$ & 102.9 & 28.5 & 2.6 \\
\hline F & 2008 & 15.3 & 1.5 & 13.4 & 0.4 & 0.0 & 0.0 \\
& 2013 & 25.9 & 0.7 & 22.6 & 2.6 & 0.0 & 0.0 \\
\hline
\end{tabular}

Source: Own elaboration based on ABDI-IPEA (2016). 
When it comes to technological intensity of the exported products, the highest value generated is related to the medium-high intensity products and the evolutionary behavior has been positive in the analyzed period, as expected for the defense industries. Comparing the sector to the average profile of Brazilian exports, this result seems more encouraging. Several authors analyzed data of the Brazilian foreign trade according to the technological intensity and the result differs considerably from those found in the Brazilian IDB Mapping. Based on the data, the balance of the value of products with medium-high intensity was negative and, in general, the products of greater prominence are those of low technology and non-industrial (De Negri 2005; Pereira, Porcile e Furtado 2001; Torezani e Campos 2013; Vogel e Azevedo 2015. As mentioned before, mediumhigh and high technological intensity products allow companies to be more competitive, which may allow a better international insertion (Dosi, Lechevalier e Secchi 2010; Dosi, Pavitt e Soete 2009).

\section{Difficulty in accessing the international market}

In the questionnaire used in the Brazilian IDB Mapping (IPEA 2016), companies were contacted in 2015 in a survey about the obstacles they faced while seeking insertion in foreign markets. Table 7 summarizes the results for all segments under analysis. Among the main difficulties related to the international market (evaluated as very high and high importance), there are: industrial protection in destination countries (78\%), unfavorable exchange rate $(69 \%)$ and internal bureaucracy (66\%), respectively.

In this market, it is common to have some protection to the companies in destination countries. However, companies do not benefit from the same (or similar) policy in the case of Brazil. In addition, unfavorable exchange rates and bureaucracy are identified as problems that reflect structural weaknesses and macroeconomic policy in the country, so they are not necessarily linked to the endogenous difficulties faced by companies and/or the particularities of the defense sector itself. Analyzing the segments individually, we realize that each one faces different obstacles, but it is noticed that the percentages indicated above are strongly influenced by the aircraft $(F)$, space $(G)$ and naval $(C)$ segments. 
Table 7. Identified obstacles by Brazilian defense-related companies when looking for external markets (2015)

\begin{tabular}{l|c|c|c|c|c}
\hline \multirow{2}{*}{ Obstacles } & \multicolumn{3}{c}{ Importance } \\
\cline { 2 - 6 } & $\begin{array}{c}\text { Very } \\
\text { high }\end{array}$ & High & Medium & Low & $\begin{array}{c}\text { Very } \\
\text { low }\end{array}$ \\
\hline Unfavorable exchange rate & $33 \%$ & $37 \%$ & $28 \%$ & $2 \%$ & $1 \%$ \\
Port and airport costs & $31 \%$ & $33 \%$ & $17 \%$ & $13 \%$ & $5 \%$ \\
International freight costs & $18 \%$ & $33 \%$ & $23 \%$ & $22 \%$ & $5 \%$ \\
Domestic transportation costs & $16 \%$ & $26 \%$ & $34 \%$ & $19 \%$ & $6 \%$ \\
Technical barriers of potential buyer countries & $11 \%$ & $31 \%$ & $37 \%$ & $18 \%$ & $2 \%$ \\
Lack of information on potential buyers' laws & $13 \%$ & $19 \%$ & $48 \%$ & $17 \%$ & $3 \%$ \\
Lack of credit & $27 \%$ & $34 \%$ & $29 \%$ & $9 \%$ & $1 \%$ \\
Lack of credit insurance (guarantees) & $29 \%$ & $35 \%$ & $23 \%$ & $11 \%$ & $2 \%$ \\
Domestic bureaucracy & $36 \%$ & $31 \%$ & $19 \%$ & $11 \%$ & $3 \%$ \\
Brazil is not associated with defense products & $15 \%$ & $29 \%$ & $43 \%$ & $11 \%$ & $2 \%$ \\
Brazilian price is not competitive with similar foreign & $23 \%$ & $37 \%$ & $27 \%$ & $13 \%$ & $1 \%$ \\
companies & & & & & \\
Brazilian quality/technology is not competitive with & $11 \%$ & $19 \%$ & $39 \%$ & $22 \%$ & $10 \%$ \\
similar foreign companies & & & & & \\
Brazilian governments from other countries support their & $48 \%$ & $30 \%$ & $19 \%$ & $3 \%$ & $1 \%$ \\
companies more than the Brazilian government does & & & & & \\
Brazilian company is not able to exhibit products at & $19 \%$ & $17 \%$ & $28 \%$ & $27 \%$ & $8 \%$ \\
international fairs abroad & & & \\
\hline
\end{tabular}

Source: Own elaboration based on ABDI-IPEA (2016).

In the segment of electronic and command and control systems (B), for example, port and airport costs, lack of credit and guarantees stand out, while in the military naval platform segment (C) the outstanding obstacles identified by companies were the public support for foreign competing companies, domestic bureaucracy and unfavorable exchange rate. On the other hand, the military ground platform segment (E) highlights that the main barriers are domestic bureaucracy and lack of guarantees, while the military aircraft platform (F) and defense-oriented space systems $(G)$ segments stress the role of government support to foreign companies, domestic bureaucracy and unfavorable exchange rate. In this way, it can be concluded that among the main obstacles identified by Brazilian defense-related companies are macroeconomic (domestic) and industrial (domestic and international) variables. 
According to CNI (2018), in 2008, $82 \%$ of Brazilian commercial companies interviewed stated that the exchange rate would be the main obstacle to exports. Airport and port costs came in second place with $41.5 \%$, followed by customs bureaucracy $(38.7 \%)$ and international freight cost (34\%), respectively. More recently, in 2018, airport and port costs appear first in the survey (51\%), while unfavorable exchange only appears in seventh place. The difficulty in offering competitive prices (43.4\%) and fees charged by consenting bodies (41.9\%) were in second and third place. Thus, there is a significant change in the obstacles identified by defense and other Brazilian companies, since the category "port and airport costs" ranked in fourth places (31.0\%) and difficulty in offering competitive prices in the seventh $(23.0 \%)$.

\section{Public instruments of export support}

Export support policies can be an important tool to boost sales abroad. In the scope of the Brazilian IDB mapping, the instruments of support provided by the Brazilian Development Bank Exim (BNDES Exim), Drawback, and BNDES' Export Financing Program (PROEX) were analyzed. Table 8 shows that Drawback has been the most widely used incentive for companies. However, it can be observed that in relation to the sample, the number of companies that used some of these instruments is very low and that there is only a small increase between 2003 and 2007.

Table 8. Export Support Instruments used by selected companies

\begin{tabular}{|c|c|c|c|c|c|c|c|c|c|c|c|c|c|c|c|c|c|c|c|c|c|}
\hline \multirow{2}{*}{ Year } & \multicolumn{7}{|c|}{ BNDES Exim } & \multicolumn{7}{|c|}{ Proex } & \multicolumn{7}{|c|}{ Drawback } \\
\hline & A & B & C & D & $\mathbf{E}$ & $\mathbf{F}$ & G & A & B & C & D & E & F & G & A & B & C & D & $\mathbf{E}$ & $\mathbf{F}$ & G \\
\hline 2003 & - & - & 3 & - & 1 & 2 & - & - & - & 5 & 1 & 4 & 1 & - & 7 & 5 & 38 & 2 & 7 & 22 & 6 \\
\hline 2004 & 1 & 1 & 3 & - & - & 2 & - & - & 1 & 5 & 1 & 5 & - & - & 9 & 9 & 39 & 2 & 8 & 24 & 9 \\
\hline 2005 & - & - & 9 & - & 4 & 2 & - & - & 2 & 5 & 2 & 2 & 1 & - & 6 & 7 & 49 & 5 & 10 & 25 & 8 \\
\hline 2006 & - & - & 4 & - & 3 & 3 & - & - & 2 & 4 & 1 & 3 & 2 & 1 & 8 & 9 & 50 & 3 & 10 & 30 & 9 \\
\hline 2007 & - & - & 7 & - & 2 & 2 & - & - & 4 & 3 & - & 2 & 6 & 2 & 9 & 9 & 45 & 2 & 12 & 30 & 9 \\
\hline
\end{tabular}

Source: Own elaboration based on ABDI-IPEA (2016).

The drawback is a support instrument that exempts tax companies from imported components and other inputs incorporated into the final product destined for products to be exported. This instrument is particularly relevant in 
the Brazilian case, given the high volume of imports at all levels of the national aircraft industry's production chain, for example. Generally, the scarce connection between the companies and the instruments of support can be an indicator of a policy failure, at least in the adhesion to the needs of the companies.

Companies may have or not knowledge/access to these instruments or the instruments themselves may not be adequate to the needs of these companies. In any case, if there is a policy and, in turn, it does not reach important companies strategically, it is possible that there is a failure in the interaction between companies and government. This is because public support has historically been critical to the productive and innovative success of defense companies, even in the case of private companies, greatly contributing to the insertion in the sector and obtaining significant plots in this market. According to Conca (1997), there have been times in the history of the Brazilian defense industry when the institutional inefficiency was responsible for its failure (Karp 1999).

\section{Final remarks}

Analyzing the defense industry and the defense market is challenging, mainly because the availability of data is often limited. In Brazil, there was still no publication that generally presented the profile of defense-related companies. The Brazilian IDB mapping published by ABDI-IPEA in 2016 constitutes an effort in this sense and offers a first approximation of these companies, although from a sectorial perspective without necessarily analyzing the defense sector as a whole. Then, this paper sought to make a conclusive and comparative synthesis of the mapping, something that has not been done at the moment of its conclusion and to date; besides we have critically analyzed the sectors, showing their main differences. Even though some data were outdated due to the lack of official and academic data, our main contribution was to analyze the "photograph" of that moment, in view of the lack of continuous data dissemination for this specific group of defense-related companies.

In this sense, it was first observed that each segment has a specific profile and, consequently, a joint analysis mitigates or even omits the perception of some differences between them. It is then believed that trying to fit the general profile of the Brazilian IDB may be useful to help understanding its limitations and critical issues. 
When it comes to international insertion of the Brazilian IDB, it is possible to conclude that the selected sample points to positive factors in relation to its competitiveness:

- Companies had an increase in the number of personnel with a higher level and an average salary higher than the national average;

- Among the companies analyzed by PINTEC, more than $70 \%$ made innovations in the analyzed period;

- Product innovations were slightly higher than innovations in process;

- The products exported are medium-high and high-tech;

- The main destination of defense-related companies are countries in the immediate region of Latin America (Argentina, Venezuela, Chile and Mexico) and countries related to international cooperation arrangements such as BRICS (China and South Africa), as well as from historical trade traditions (US and EU); and

- The main barriers to insertion are on average more related to structural and macroeconomic issues, rather than to internal business conditions.

Despite limitations in terms of data and time period analyzed, which cannot complete or exhaust the subject, it was possible to draw an initial and general profile of the industry (detailed by different segments) and to define relevant issues that need further analysis (such as personnel profile, technological innovation profile, destination markets, and types of financing).

One of the main features of the defense products market are its barriers, so it is not surprising that this was the main difficulty pointed out by companies. This difficulty could be overcome by offering innovative products. However, the innovative profile is still focused on process and shows weakness in product innovations. This feature may limit the competitiveness of companies. In the same line, the fact that exports are mainly destined for South American countries, neighbors and Mercosur partners, without involvement in conflicts, corroborates the difficulty of inserting the products of Brazilian companies operating in the defense area.

Among the possible related issues that come from this debate, there are challenges of political and economic nature, which require greater debate and transparency in the defense sector in general, and in the case of Brazil in particular. Therefore, the contribution of this paper is paramount to finally present an overview of the sector so that industry itself, academia, policymakers and other stakeholders have a better knowledge of the sector's profile, size, challenges and opportunities of Brazilian defense. 


\section{References}

ABDI-IPEA. Mapeamento da Base Industrial de Defesa. Brasília: Ipea, 2015.

Abdul-Hak, Ana Patrícia N. T. 2013. O Conselho de Defesa Sul-Americano (CDS): objetivos e interesses do Brasil. Brasília: Fundação Alexandre de Gusmão, 2013. Disponível em: < http://www.funag.gov.br/ipri/btd/index.php/11-aprovadas-cae/3431-oconselho-de-defesa-sul-americano-cds-objetivos-e-interesses-do-brasil > . Acesso em: 01 dez. 2019.

Aghion, Philippe; Bergeaud, Antonin; Lequien, Matthieu; Melitz, Marc J. 2018. "The Impact of Exports on Innovation: Theory and Evidence". Working papers, v. 678, Banque de France. Disponível em: < https://scholar.harvard.edu/files/melitz/files/ innovation-exporting_link.pdf > . Acesso em: 03 fev. 2020.

Aghion, Philippe; Howitt, Peter. 2009. The economics of growth. MIT Press. Disponível em: < https://mitpress.mit.edu/books/economics-growth > . Acesso em: 28 jan. 2020.

Akerman, Anders; Seim, Anna Larsson. 2014. "The global arms trade network 1950-2007”. Journal of Comparative Economics 42: 535-551. Disponível em: $<$ https://www.sciencedirect.com/science/article/pii/S0147596714000171 > . Acesso em: 22 jan. 2020.

Álvarez, Roberto; García, Álvaro. 2008. "Productividad, innovación y exportaciones en la industria manufacturera chilena". Working Papers of the Central Bank of Chile 476: 1-29. Disponível em: < https://www.jstor.org/stable/20857246?seq =1 > . Acesso em: 18 jan. 2020.

Anderton, Charles H. 1995. "Economics of the arms trade". In Hartley, Keith; Sandler, Todd (Eds.). Handbook of defense Economics. Amsterdam: North-Holland, 523-590. Disponível em: < https://www.sciencedirect.com/handbook/handbook-of-defenseeconomics/vol/1/suppl/C > . Acesso em: 15 jan. 2020.

Aránguiz, Javiera B. 2013. "El Consejo de Defensa Suramericano y las nuevas amenazas". Revista Enfoques 11, no. 19: 53-75. Disponível em: < http://www.revistaenfoques. cl/index.php/revista-uno/article/view/41 > . Acesso em: $01 \mathrm{dez} .2019$.

Arredondo, Gustavo A. 2017. "UNASUR y el Consejo de Defensa Suramericano en su primer lustro 2011-2016”. Revista de Marina 957: 18-25. Disponível em: < https:// revista.esg.br/index.php/revistadaesg/article/view/946 > . Acesso em: 15 jan. 2020. Atkeson, Andrew; Burstein, Ariel T. 2010. "Innovation, Firm Dynamics, and International Trade”. Journal of Political Economy 118, no. 3: 433-484. Disponível em: < http:// www.econ.ucla.edu/arielb/innovation.pdf > . Acesso em: 06 jan. 2020.

Balassa, Bela. 1978. "Exports and economic growth: further evidence”. J. Dev. Econ. 5, no. 2: 181-189. Disponível em: < https://www.sciencedirect.com/science/article/ abs/pii/0304387878900068 > . Acesso em: 25 jan. 2020. 
Balassa, Bela. 1985. "Exports policy choices, and economic growth in developing countries after the 1973 oil shock”. J. Dev. Econ. 18: 23-35. Disponível em: < https://www.science direct.com/science/article/abs/pii/0304387885900045 > . Acesso em: 25 jan. 2020.

Becker, Sascha O.; Egger, Peter H. 2013. "Endogenous Product versus Process Innovation and a Firm's Propensity to Export”. Empirical Economics 44: 329-354. Disponível em: < https://link.springer.com/article/10.1007/s00181-009-0322-6 > Acesso em: 14 dez. 2019.

Bitizinger, Richard A. 2015. "Defense Industries in Asia and the Technonationalist Impulse”. Contemporary Security Policy 36, no. 3: 453-472. Disponível em: < https:// www.tandfonline.com/doi/abs/10.1080/13523260.2015.1111649?journalCode = fc sp20 > . Acesso em: 23 dez. 2019.

Blo, Martin; Castellacci, Fulvio; Fevolden, Arne. 2014. "Defence Firms Facing Liberalization: innovation and export in an agent-based model of the defence industry". Comput Math Organ Theory 20: 430-461. Disponível em: < https://link.springer.com/ article/10.1007/s10588-014-9173-6 > . Acesso em: 13 nov. 2019.

Brzoska, Michael. 2004. "The economics of arms imports after the end of the cold war". Defence and Peace Economics 15, no. 2: 111-123. Disponível em: < https://www. researchgate.net/publication/24078221_The_Economics_of_Arms_Imports_After_ the_End_of_the_Cold_War >. Acesso em: 13 dez. 2019.

Caldera, Aida. 2010. "Innovation and Exporting: Evidence from Spanish Manufacturing Firms”. Review of World Economics 146, no. 4: 657-689. Disponível em: < https:// link.springer.com/article/10.1007/s10290-010-0065-7 > . Acesso em: 01 mar. 2020.

Carranza, Mario E. 2017. "Rising powers and international order: comparing Brazil and India's strategies for admission to the great power club”. Contemporary Security Policy 38, no. 3: 491-498. Disponível em: < https://www.tandfonline.com/doi/ab s/10.1080/13523260.2017.1351654 > . Acesso em: 01 mar. 2020.

Cassiman, Bruno; Golovko, Elena. 2011. "Innovation and Internationalization through Exports”. Journal of International Business Studies 42, no. 1: 56-75. Disponível em: < https://link.springer.com/article/10.1057/jibs.2010.36 > . Acesso em: 01 fev. 2020.

Catela, Eva Yamilla da S.; Gonçalves, Flávio de O. 2011. "Intensidade tecnológica das exportações mundiais: uma análise de misturas finitas e do "learning-by-exporting" como determinante”. Nova Economia 21, no. 3: 369-393. Disponível em: < http://www. scielo.br/scielo.php?pid $=$ S0103-63512011000300003\&script $=$ sci_abstract\&tlng $=$ pt $>$. Acesso em: 17 fev. 2020.

Conca, Ken. 1997. Manufacturing Insecurity: The Rise and Fall of Brazil's Military-Industrial Complex. Boulder: Lynne Rienner. Disponível em: < https://www.amazon.com/ Manufacturing-Insecurity-Brazils-Military-Industrial-Complex/dp/1555876951 > . Acesso em: 09 jan. 2020. 
Confederação Nacional das Indústrias (CNI). 2018. Desafios à competitividade das exportações brasileiras. Brasília: CNI. Disponível em: < http://www.portaldaindustria. com.br/publicacoes/2016/8/desafios-competitividade-das-exportacoes-brasileiras / > . Acesso em: 10 fev. 2020.

Cuaresma, Jesús C.; Wörz, Julia. 2005. “On export composition and growth”. Rev. World Econ. 141, no. 1: 33-49. Disponível em: < https://www.jstor.org/stable/40441033 > . Acesso em: 27 jan. 2020.

Dagnino, Renato P. 2008. "Em que a Economia de Defesa pode ajudar nas decisões sobre a revitalização da Indústria de Defesa brasileira?” Oikos 1: 113-137.

Damijan, Jože; Kostevc, Črt; Polanec, Saso. 2010. "From Innovation to Exporting or Vice Versa?" The World Economy 33, no. 3: 374-398. Disponível em: < https://online library.wiley.com/doi/10.1111/j.1467-9701.2010.01260.x > . Acesso em: 23 jan. 2020.

Delgado, Miguel A.; Fariñas, Jose C.; Ruano, Sonia. 2002. "Firm productivity and export markets: A non-parametric approach”. Journal of International Economics 57: 397-422. Disponível em: < https://www.sciencedirect.com/science/article/ abs/pii/S0022199601001544 > . Acesso em: 25 jan. 2020.

De Negri, Fernanda. 2005. "Padrões tecnológicos e de comércio exterior das firmas brasileiras”. In: De Negri, João A.; Salermo, Mario S. Inovações, padrões tecnológicos e desempenho das firmas industriais brasileiras. Brasília: IPEA, 75-118.

Dosi, Giovanni, Grazzi, Marco; Moschella, Daniele. 2015. “Technology and costs in international competitiveness: From countries and sectors to firms”. Research Policy 44: 1795-1814. Disponível em: < https://www.sciencedirect.com/science/article/ abs/pii/S0048733315000888 > . Acesso em: 19 dez. 2019.

Dosi, Giovanni; Lechevalier, Sébastien; Secchi, Angelo. 2010. "Introduction: Interfirm heterogeneity: nature, sources and consequences for industrial dynamics”. Industrial and Corporate Change 19, no. 6: 1867-1890. Disponível em: < https://academic. oup.com/icc/article/19/6/1867/734438 > . Acesso em: 17 dez. 2019.

Dosi, Giovanni; Pavitt, Keith; Soete, Luc. 2009. The Economics of Technical Change and International Trade. Brighton, Wheatsheaf and New York: New York University Press. Disponível em: < https://econpapers.repec.org/bookchap/ssalembks/dosietal-1990. htm > . Acesso em: 06 jan. 2020.

Dunne, J. Paul. 1995. “The Defense Industrial Base”. In Hartley, Keith; Sandler; Todd (Eds.). Handbook of Defence Economics. Amsterdam: Elsevier, 399-430. Disponível em: < https://www.sciencedirect.com/handbook/handbook-of-defense-economics/ vol/1/suppl/C > . Acesso em: 19 dez. 2019.

Fernandes, Ana M.; Isgut, Alberto E. 2005. "Learning-by-doing, learning-by- exporting, and productivity: evidence from Colombia”. World Bank Policy Research Working Paper, no. 3544. Disponível em: < http://documents.worldbank.org/curated/ 
en/877071468744313107/Learning-by-doing-learning-by-exporting-and-productivityevidence-from-Colombia > . Acesso em: 24 nov. 2019.

Fonfría, Antonio; Duch-Brown, Néstor. 2014. "Explaining Export Performance in the Spanish Defense Industry”. Defence and Peace Economics 25, no. 1: 51-67. Disponível em: < https://www.tandfonline.com/doi/abs/10.1080/10242694.2013.857460?jou rnalCode $=$ gdpe20 > . Acesso em: 04 dez. 2019.

Freeman, Chris; Soete, Luc. 2008. A Economia da Inovação Industrial. Campinas: Editora Unicamp.

Freund, Caroline; Pierola, Martha D. 2012. “Export Surges”. Journal of Development Economics 97: 387-395. Disponível em: < https://econpapers.repec.org/article/ eeedeveco/v_3a97_3ay_3a2012_3ai_3a2_3ap_3a387-395.htm > . Acesso em: 28 nov. 2019.

Fuccille, Alexandre. 2018. "Brasil e o Conselho de Defesa Sul-americano (CDS): um balanço de uma década de sua existência”. In $11^{\circ}$ Encontro da Associação Brasileira de Ciência Política (ABCP), Curitiba. Disponível em: < https://cienciapolitica.org. br/_arquivos/encontro-abcp-2018/arquivos/BYHK.pdf > . Acesso em: 17 dez. 2019.

Garcia-Alonso, M.; Levine, P. 2007. “Arms Trade and Arms Races: A Strategic Analysis”. In Sandler, Todd; Hartley, Keith (Eds.). Handbook of Defense Economics. Amsterdam: Elsevier, 941-971. Disponível em: < https://econpapers.repec.org/bookchap/ eeehdechp/2-29.htm > . Acesso em: 03 fev. 2020.

Grossman, Gene M.; Helpmanz, Elhanan. 1989. "Quality Ladders in the Theory of Growth”. The Review of Economic Studies 58, no. 1: 43-61. Disponível em: < https:// www.nber.org/papers/w3099 > . Acesso em: 04 fev. 2020.

Hatzichronoglou, Thomas. 1997. "Revision of the High-Technology Sector and Product Classification”. OECD Science, Technology and Industry. Paris: OECD Publishing. Disponível em: < https://www.oecd-ilibrary.org/science-and-technology/revisionof-the-high-technology-sector-and-product-classification_134337307632 > . Acesso em: 20 jan. 2020.

Hausmann, Ricardo; Hwang, Jason; Rodrik, Dani. 2007. "What You Export Matters”. Journal of Economic Growth 12, no. 1: 1-25. Disponível em: < https://www.nber. org/papers/w11905 > . Acesso em: 20 dez. 2019.

Heckscher, Eli F. 1991. "The Effects of Foreign Trade on the Distribution of Income”. In Heckscher, Eli F.; Ohlin, Bertil (Eds.). Heckscher-Ohlin trade Theory. Cambridge, MA: The MIT Press.

IBGE. Pesquisa de Inovação: PINTEC 2011. Rio de Janeiro: IBGE, 2011.

IBGE. Pesquisa Nacional por Amostra de Domicílios: PNAD 2013. Rio de Janeiro: IBGE, 2013. 
IBGE. Estatísticas do Cadastro Central de Empresas: CEMPRE. Rio de Janeiro, IBGE, 2014. Karp, Aaron. 1999. "Ideology, politics and proliferation: Learning from the rise and fall of Brazil”. Contemporary Security Policy 20, no. 1: 130-136. Disponível em: < https://www.tandfonline.com/doi/abs/10.1080/13523269908404214 > Acesso em: 25 jan. 2020.

Kinsella, David. 2011. “The arms trade”. In Coyne; Christopher J.; Mathers, Rachel L. (Eds.), Handbook on the Political Economy of War. Edward Elgar: Cheltenham, UK, 217-242. Disponível em: < https://www.researchgate.net/publication/228680251_ Changing_structure_of_the_arms_trade_A_social_network_analysis > . Acesso em: 23 jan. 2020.

Krause, Keith. 1995. Arms and the State: Patterns of Military Production and Trade. Cambridge: Cambridge University Press.

Krugman, Paul R. 1981. "Intraindustry specialization and the gains from trade”. Journal of Political Economy 89, no. 51: 956-73. Disponível em: < https://www.journals. uchicago.edu/doi/abs/10.1086/261015 > . Acesso em: 01 mar. 2020.

Leske, Ariela D. C. 2018. "A review on defense innovation: from spin-off to spin-in". Revista de Economia Política 38: 377-39. Disponível em: < http://www.rep.org.br/ issue_detail.asp?cod $=1590>$. Acesso em: 02 mar. 2020.

Leske, Ariela D. C. 2015. “Interação, Inovação e Incentivos na Indústria de Defesa Brasileira”. Política Hoje 24: 27-50. Disponível em: < https://periodicos.ufpe.br/ revistas/politicahoje/article/view/3731 > . Acesso em: 14 jan. 2020.

Levine, Paul; Smith, Ron; Reichlin, Lucrezia; Rey, Patrick. 1997. “The arms trade”. Economic Policy 12, no. 25: 335-370. Disponível em: < https://www.jstor.org/ stable/1344683 > . Acesso em: 07 dez. 2019.

Lo Turco, A.; Maggioni, D. 2014. "Dissecting the impact of innovation on exporting in Turkey”. Economics of Innovation and New Technology 24, no. 4: 309-338. Disponível em: < https://www.tandfonline.com/doi/abs/10.1080/10438599.2014.946311?jour nalCode $=$ gein20 $>$. Acesso em: 10 dez. 2019.

Martinez, Elis David M.; Lyra, Mariana P. O. de. 2018. “O Papel da UNASUL nas Crises Democráticas Sul-Americanas (2008-2015)”. Carta Internacional 13, no. 1: 98126. Disponível em: < https://www.cartainternacional.abri.org.br/Carta/article/ view/729/375 > . Acesso em: 01 dez. 2019.

Matos, Patricia de O.; Fingolo, Julie M.; Schneider, Raphael A. 2017. “Orçamento Público e Defesa Nacional: uma análise do Orçamento de Defesa Brasileiro no Período de 2000 a 2016". Revista da Escola de Guerra Naval 23, no. 1: 211-238. Disponível em: < https://revista.egn.mar.mil.br/index.php/revistadaegn/article/view/551 > . Acesso em: 17 dez. 2019. 
Melitz, Marc J. 2003. “The impact of trade on intra-industry reallocations and aggregate industry productivity”. Econométrica 71: 1695-1725. Disponível em: < https://scholar. harvard.edu/files/melitz/files/aggprod_ecma.pdf > . Acesso em: 14 nov. 2019.

Ohlin, Bertil. 1991. “The Theory of Trade”. In Heckscher, Eli F.; Ohlin, Bertil (Eds.). Heckscher-Ohlin trade Theory. Cambridge, MA: The MIT Press.

Organization of Economic Cooperation and Development (OECD). 2011. ISIC Rev. 3 Technology Intensity Definition. Disponível em: < http://www.oecd.org/sti/ind/ 48350231.pdf > . Acesso em: 07 jan. 2020.

Organization of Economic Cooperation and Development (OECD). 2015. List of OECD Member countries - Ratification of the Convention on the OECD, 2015. Disponível em: < http://www.oecd.org/about/membersandpartners/list-oecd-member-countries. htm > . Acesso em: 06 jan. 2020.

Padula, Raphael. 2015. "A disputa pela agenda de segurança regional e o Conselho de Defesa Sul-americano”. Revista da Escola de Guerra Naval 21, no. 2: 221-262. Disponível em: < https://revista.egn.mar.mil.br/index.php/revistadaegn/article/ view/173/135 > . Acesso em: 01 dez. 2019.

Pagliari, Graciela C. 2015. “Conselho de Defesa Sul-Americano e a adoção de medidas de fortalecimento da confiança”. Carta Internacional 10: p. 23-40. Disponível em: < https://www.cartainternacional.abri.org.br/Carta/article/view/307/256 > Acesso em: 15 dez. 2019.

Pamp, Oliver; Thurner, Paul O. 2017. "Trading Arms and the Demand for Military Expenditures: Empirical Explorations Using New SIPRI-Data”. Defence and Peace Economics 28, no. 4: 457-472. Disponível em: < https://www.tandfonline.com/ doi/abs/10.1080/10242694.2016.1277452 > . Acesso em: 20 dez. 2019.

Pereira, Wellignton; Porcile, Gabriel; Furtado, João. 2011. “Competitividade internacional e tecnologia: uma análise da estrutura das exportações brasileiras”. Economia e Sociedade 20, no. 3: 501-531. Disponível em: < http://www.scielo.br/scielo.php? script = sci_abstract\&pid $=$ S0104-06182011000300003\&lng $=$ en\&nrm $=$ iso\&tlng $=$ pt > . Acesso em: 13 dez. 2019.

Perkins, Richard; Neumayer, Eric. 2002. "The organized hypocrisy of foreign policy: human rights, democracy and western arms sales”. Geoforum 89: 247-256. Disponível em: < https://www.sciencedirect.com/science/article/abs/pii/S0016718509001249> . Acesso em: 12 dez. 2019.

Raiher, Augusta P.; Carmo, Alex Sander S. do; Stege, Aysson L. 2017. "The effect of technological intensity of exports on the economic growth of Brazilian microregions: A spatial analysis with panel data”. EconomiA 18, no. 3: 275-432. Disponível em: < https://www.sciencedirect.com/science/article/pii/S1517758016301060 > . Acesso em: 20 fev. 2020. 
Rezende, Lucas P. 2016. “Brasil: ator unipolar na América do Sul?” Carta Internacional 11, no. 1: 274-295. Disponível em: < https://www.cartainternacional.abri.org.br/ Carta/article/view/355/307 > . Acesso em: 02 mar. 2020.

Rodríguez, José López; Rodríguez, Jesús López. 2005. “Technological Resources and Export Intensity: A Microview”. International Business \& Economics Research Journal 4, no. 11: 55-64. Disponível em: < https://www.researchgate.net/publication/268400650_ Technological_Resources_And_Export_Intensity_A_Microview > . Acesso em: 03 fev. 2020.

Salomon, Robert M.; Shaver, J. 2005. "Myles. Learning-by-exporting: New insights from examining firm innovation”. Journal of Economics and Management Strategy 14, no. 2: 431-461. Disponível em: < https://onlinelibrary.wiley.com/doi/abs/10.1111/j. 1530-9134.2005.00047.x > . Acesso em: 28 jan. 2020.

Santos, Marcos C. 2018a. Construindo inimigos para a América do Sul: os discursos de segurança no Conselho de Defesa da Unasul. Curitiba: Editora Appris.

Santos, Thauan. 2018b. “Economia de Defesa como uma Categoria Geral de Análise nas Ciências Econômicas”. Revista da Escola de Guerra Naval 23, no. 3: 543-565. Disponível em: < https://revista.egn.mar.mil.br/index.php/revistadaegn/article/ view/763 > . Acesso em: 07 jan. 2020.

Santos, Thauan; Rodrigues, Bernardo S.; Leite, Ana Paula M. R. 2019. "Diez Años y Soledad: a breve existência do Conselho de Defesa Sul-Americano da UNASUL (2008-2018)”. In XVII Fórum Universitário do Mercosul (FoMerco), Foz do Iguaçu. Disponível em: < https://www.congresso2019.fomerco.com.br/resources/anais/9/ fomerco2019/1568848319_ARQUIVO_548dd6afcd1e9e726d05136f23fbd025.pdf > . Acesso em: 19 jan. 2020.

Sharp, G. 2005. "The economic costs and benefits of UK defence exports: a comment”. Defence and Peace Economics 16, no. 1: 59-66. Disponível em: < https://www. tandfonline.com/doi/abs/10.1080/1024269052000323551 ?journalCode $=$ gdpe20 > . Acesso em: 05 jan. 2020.

Souza, Tamires, A. F. 2016. "As razões de existência do Conselho de Defesa Sul-Americano da UNASUL”. Carta Internacional 3, no. 2: 124-148. Disponível em: < https://cartainternacional.abri.org.br/Carta/article/view/485/331 > . Acesso em: 16 dez. 2019.

Suaréz-Porto, Vanessa; Guisado-González, Manuel. 2014. “Analysis of the determinants of exporting intensity in the field of innovation". Investigaciones Europeas de Dirección y Economía de la Empresa 20, no. 2: 79-86. Disponível em: < https://www. sciencedirect.com/science/article/pii/S1135252314000045 > . Acesso em: 21 out. 2019.

Torezani, T. A.; Campos, A. C. 2013. “Tecnologia e competitividade: a evolução das teorias do comércio internacional”. In Encontro Nacional de Economia Política, 
Belo Horizonte, $\mathrm{n}^{\mathrm{o}}$ 18, Sociedade Brasileira de Economia Política. Disponível em: http://www.sep.org.br/artigos > . Acesso em: 21 ago. 2019.

Vernon, Raymond. 1966. "International Investment and International Trade in the Product Cycle”. Quarterly Journal of Economics 80: 190-207. Disponível em: < https://www. jstor.org/stable/1880689 > . Acesso em: 14 nov. 2019.

Villa, Rafael D.; Bragatti, Milton C. 2015. “Complexificação das Instituições de defesa na América do Sul”. Carta Internacional 10, no. 3: 4-22. Disponível em: < https://www. cartainternacional.abri.org.br/Carta/article/view/245/255 > . Acesso em: 01 dez. 2019. Villa, Rafael D.; Weiffen, Brigitte. 2014. "South American Re-armament: From Balancing to Symbolizing Power”. Contemporary Security Policy 35, no. 1: 138-162. Disponível em: < https://www.tandfonline.com/doi/abs/10.1080/13523260.2014.884342 > . Acesso em: 01 dez. 2019.

Vogel, G.; Azevedo, A. F. Z. 2015. “Intensidade Tecnológica das Exportações do Brasil e de Estados Selecionados (2000-2010)”. Revista de Administração da UFSM 8, no. 1: 26-41, 2015.

\section{Appendix 1}

\begin{tabular}{|c|c|}
\hline Year & Nominal exchange rate \\
\hline 2000 & 1,83 \\
2001 & 2,35 \\
2002 & 2,92 \\
2003 & 3,08 \\
2004 & 2,93 \\
2005 & 2,43 \\
2006 & 2,18 \\
2007 & 1,95 \\
2008 & 1,83 \\
2009 & 2,00 \\
2010 & 1,76 \\
2011 & 1,68 \\
2012 & 1,96 \\
2013 & 2,16 \\
2014 & 2,35 \\
2015 & 3,33 \\
2016 & 3,49 \\
\hline
\end{tabular}

Source: Own elaboration based on Ipeadata database. Nominal exchange rates were calculated based on the average of nominal monthly exchange rates from the official Brazilian government database. Available at: < http://ipeadata.gov.br/ExibeSerie. aspx? serid $=38389>$. 